\title{
Hubungan Metode Pembelajaran Discovery terhadap Hasil Belajar Menggambar Bentuk Peserta Didik Sekolah Menengah Atas Negeri 1 Pollung
}

\section{The Relationship of Discovery Learning Methods to The Outcomes of Learning to Draw The Shapes of Students of Pollung 1 High School}

\author{
Yunniko Anrio Pandiangan \& Sugito* \\ Program Studi Pendidikan Seni Rupa Fakultas Bahasa Dan Seni \\ Univeresitas Negeri Medan, Indonesia
}

Diterima: 11 Mei 2021 Direview: 11 Mei 2021; Disetujui: 06 Agustus 2021 * Coresponding Email: sugitoas@gmail.com

\begin{abstract}
Abstrak
Penelitian ini bertujuan untuk mengetahui apakah ada hubungan antara metode pembelajan discovery terhadap hasil belajar menggambar bentuk. Adapun populasi dalam penelitian ini adalah seluruh peserta didik kelas X SMA Negeri 1 Pollung yang mengikuti pelajaran menggambar bentuk dengan jumlah 288 peserta didik dan sampelnya yang berjumlah 40 orang yaitu setiap kelas terdiri dari 5 peserta didik dengan pengambilan sampel menggunakan teknik Sampling Kuota. Metode penelitian ini menggunakan penelitian correlational research.Hasil temuan penelitian ini menunjukkan bahwa terdapat korelasi kemampuan menggambar bentuk dengan metode pembelajaran discovery (X1) dengan hasil belajar menggambar bentuk (Y) $t_{\text {hitung }}=30,20$ untuk DK $=\mathrm{n}-2=38 \alpha=0,05 t_{\text {tabel }}=1,684$ ternyata $t_{\text {hitung }}>$ $t_{\text {tabel }}(30,20>1,684)$, kemampuan menggambar bentuk dengan metode pembelajaran discovery (X2) dengan hasil belajar menggambar bentuk (Y) $t_{\text {hitung }}=3,46$ untuk DK $=\mathrm{n}-2=38 \alpha=0,05 t_{\text {tabel }}=1,684$ ternyata $t_{\text {hitung }}>t_{\text {tabel }}(3,46>1,684)$. Besar hubungan antara kemampuan menggambar bentuk $\left(X_{1}\right)$ $\left(X_{2}\right)$ dengan hasil belajar menggambar bentuk (Y) berkorelasi 0,98 dan 0,49, dan besar sumbangan $96 \%$ dan $24 \%$.
\end{abstract}

Kata Kunci : hubungan; Metode Discovery; Gambar Bentuk

\section{Abstract}

Study aims to determine whether there is a relationship between the discovery learning method and the results of learning to draw shapes.The population in this study were all students of class X SMA Negeri 1 Pollung who took shape drawing lessons with a total of 288 students and a sample of 40 people, namely each The class consists of 5 students with sampling using the Quota Sampling technique. This research method uses correlational research. The findings of this study indicate that there is a correlation between the ability to draw shapes with the discovery learning method (X1) with the results of learning to draw shapes (Y) $t_{\text {count }}=30.20$ for $D K=n-2=38 \alpha=0.05$ ttable $=1.684$ turns out that $t_{\text {count }}>t_{\text {table }}(30.20>1.684)$, the ability to draw shapes using discovery learning method (X2) with the result of learning to draw shapes (Y) $t_{-}$count $=3.46$ for $D K=n-2=38 \alpha=0.05 t_{\text {table }}=1.684$ turns out that $t_{\text {count }}>t_{\text {table }}(3.46>1.684)$. The magnitude of the relationship between the ability to draw shapes $\left(X \_1\right)\left(X \_2\right)$ with learning outcomes to draw shapes (Y) has a correlation of 0.98 and 0.49 , and the contribution is $96 \%$ and $24 \%$.

Keywords: relationship; Discovery Method; Image Form

How to Cite: Pandiangan, Y.A. \& Sugito, (2021). Hubungan Metode Pembelajaran Discovery Terhadap Hasil Belajar Menggambar Bentuk Peserta Didik Sekolah Menengah Atas Negeri 1 Pollung Journal of Education, Humaniora and Social Sciences (JEHSS). 4(2): 671-676. 


\section{PENDAHULUAN}

Seni budaya merupakan salah satu mata pelajaran di Sekolah Menengah Atas dengan menerapkan berbagai bidang kesenian, diantaranya bidang seni rupa. Dalam mata pelajaran tersebut guru memberi pelajaran kepada siswa di sekolah tentang nilai estetika dimana hal yang dapat ditangkap oleh indra disampaikan ke dalam bentuk rasa, dan nilai artistik yang mempelajari tentang hubungan dengan wujud yang indah, dan kreatif yang berpedoman pada nilai, norma, perilaku, seni dan budaya di Indonesia.

Dalam pendidikan seni rupa, menggambar adalah mata pelajaran pokok. Banyak metode menggambar yang diajarkan sebagai pilihan yang dapat diterapkan dalam pembelajaran seni rupa, khususnya dalam menggambar bentuk. Melalui studi pendahuluan dengan cara observasi awal di SMA Negeri 1 Pollung, penulis menemukan salah satu kegiatan peserta didik dalam mata pelajaran seni budaya khususnya pada bagian seni rupa adalah menggambar dua dimensi (menggambar bentuk). Dimana dalam proses pembelajaran guru cenderung menerapkan metode konvensional, seperti metode penugasan yang relevan dengan karakteristik materi pembelajaran kurang sesuai. Terlebih dengan minat,dan keterampilan peserta didik dalam menggambar. (Paramita dkk, 2020).

Dalam menggambar bentuk peserta didik masih belum menguasai proporsi sehingga gambar terlihat kurang menarik. Seni Budaya juga sangat berpengaruh pada hasil karya. Untuk memberikan motivasi dan semangat belajar yang tinggi maka, kemampuan dalam renggambar bentuk perlu ditingkatkan. Guru sebaiknya lebih bervariasi dalam metode pembelajaran agar kreatifitas serta hasil belajar siswa dalam menggambar bentuk dapat ditingkatkan lagi.

Adapun beberapa penelitian yang dilakukan sebelumnya, diantaranya adalah penelitian Regi Firga Ningsih (2016) dalam penelitiannya yang berjudul “ Penggunaan Metode Discovery Learning Bermedia Audio Visual Terhadap Hasil Belajar Menggambar Bentuk " menyatakan bahwa metode pembelajaran discover bermedia audio visual dengan hasil belajar menggambaar bentuk. Penelitian yang dilakukan pada siswa kelas VII SMP N 2 Padang Genting menyatakan adanya perbedaan dalam proses pembelajaran tetapi dalam kegiatan meggambar bentuk masih tetap sama. Dimana dalam proses pembelajaran Discovery bermedia audio visual berada pada kualifikasi baik .(B) dengan nilai rata - rata 78,77. Dibandingkan Menggambar bentuk dengan menggunakan metode konvensional dengan nilai rata - rata 73. Dengan pernyataan tersebut dapat dikatakan bahwa metode pembelajaran Discovery bermedia audio visual berperan penting dalam hasil belajar menggambar bentuk. (Yakob \& Sari, 2019).

Faizah (2012) dalam penelitiannya yang berjudul “ Upaya Meningkatkan Kreativitas Siswa Dalam Menggambar Motif Batik Dengan Metode Discovery-Inquiry Di Kelas VII A SMP Negeri 2 Simo Boyolali Tahun Ajaran 2012/2013" mengatakan bahwa faktor penghambat siswa dalam menggambar motif batik adalah kurangnya penguasaan siswa akan motif - motif batik yang merupakan dasar dari menggambar motif batik.Siswa masih kurang terbekali dalam keteramilan latihan - latihan yang cukup dalam menggambar motif batik, seperti membuat sketsa batik maupun latihan yang bersifat teoritis.

Seorang pelajar tentu pertama sekali akan mulai menggambar dengan sangat perlahan dan hati-hati, itu berarti mengambar bukanlah suatu hal yang mudah. Sehingga penulis merasa perlu mengenalkan metode pembelajaran menggambar yakni metode Discovery untuk digunakan dalam pembelajaran menggambar bentuk. Disini penulis fokus meneliti hubungan metode tersebut dalam menggambar bentuk.

\section{METODE PENELITIAN}

Penelitian ini dilakukan di SMA Negeri 1 Pollung yang beralamat di JL.JD Marbun , Huta Paung, kecamatan Pollung, Sumatera Utara. Populasi yang ditentukan dalam penelitian ini adalah siswa kelas X SMA Negeri 1 Pollung yang terdiri dari dari 8 kelas yaitu X IPA 1, X IPA 2, X IPA 3, XIPA 4, X IPS 1, X IPS 2, X IPS3, X IPS 4 dengan jumlah setiap kelasnya adalah 36 siswa, sehingga jumlah keseluruhan adalah 288 siswa.

Teknik pengambilan sampel dilakukan dengan cara sampling Kuota yaitu sampel yang diambil berdasarkan jumlah yang diinginkan. Dari 8 kelas diperoleh 40 peseta didik sebagai 
sampel penelitian. Metode penelitian yang digunakan dalam penelitian ini adalah penelitian korelasional (correlational research) penelitian yang melihat hubungan antara dua gejala ( variabel). Penelitian ini adalah penelitian yang bertujuan mengetahui sejauh mana variabel variabel berkaitan ( berhubungan ) berdasarkan koefisien korelasi.

Untuk mengumpulkan data dalam penelitian ini dilakukan dengan menggunakan teknik tes. Teknik tes yang dimaksud adalah tes kemampuan menggambar bentuk. Cara memperoleh data yang digunakan dalam penelitian menggunakan daftar penilaian hasil karya dengan indikator yang tampak sesuai dengan hasil pengumpulan data berdasarkan tabel dibawah :

Tabel 1 Format Penilaian Karya Menggambar Bentuk

\begin{tabular}{|c|c|c|c|c|c|c|}
\hline No & Indikator & Bobot & Deskriptor & $\begin{array}{l}\text { Rentang } \\
\text { skor }\end{array}$ & Skor & Penilaian \\
\hline 1 & $\begin{array}{l}\text { Proses } \\
\text { penemuan } \\
\text { (discoveri) }\end{array}$ & 10 & $\begin{array}{l}\text { Kesesuaian gambar bentuk dengan objek } \\
\text { yang pahami sendiri }\end{array}$ & 10 & & \multirow{16}{*}{$\begin{array}{l}=\frac{\sum X}{\sum N} \\
\text { Standar } \\
\text { rentang } \\
\text { skor :90-10o = } \\
\text { A } \\
\text { ( Sangat baik) } \\
80-89=\mathrm{B} \text { ( } \\
\text { baik) } \\
70-79=\mathrm{C}( \\
\text { kurang baik) } \\
\text { o-69 = E ( } \\
\text { sangat } \\
\text { buruk) } \\
\text { (Unimed, } \\
\text { 2018) }\end{array}$} \\
\hline \multirow[t]{2}{*}{2} & Garis & \multirow[b]{2}{*}{10} & $\begin{array}{l}\text { Terciptanya garis arsiran yang natural dan } \\
\text { luwes. }\end{array}$ & $1-5$ & & \\
\hline & & & Garis memiliki kerapian dan jelas. & $1-5$ & & \\
\hline \multirow[t]{2}{*}{3} & Perspektif & & $\begin{array}{l}\text { Ketetapan benda yang dekat dengan mata } \\
\text { akan terlihat lebih besar atau lebih tinggi dari } \\
\text { pada benda yang terletak lebih jauh dari mata }\end{array}$ & $1-10$ & & \\
\hline & & 20 & $\begin{array}{l}\text { Jarak pandang mata terhadap objek sesuai } \\
\text { dengan bentuk objek aslinya. }\end{array}$ & $1-10$ & & \\
\hline \multirow[t]{4}{*}{4} & Proporsi & 20 & $\begin{array}{l}\text { Perbandingan objek yang ideal yang dapat } \\
\text { diserap oleh persepsi pengamat. }\end{array}$ & $1-5$ & & \\
\hline & & & $\begin{array}{l}\text { Ukuran dari sutau unsur yang disusun, sejauh } \\
\text { mana ukuran itu menunjang. }\end{array}$ & $1-5$ & & \\
\hline & & & $\begin{array}{l}\text { Penyesuaian benda yang satu dengan yang } \\
\text { lainnya. }\end{array}$ & $1-5$ & & \\
\hline & & & $\begin{array}{l}\text { Penyesuaian proporsi antara objek dengan } \\
\text { bidang gambar. }\end{array}$ & $1-5$ & & \\
\hline \multirow[t]{3}{*}{5} & Komposisi & 15 & $\begin{array}{l}\text { Penyusunan objek gambar pada bidang kertas } \\
\text { sesuai dengan model yang ditiru dab sesuai } \\
\text { dengan keindahan komposisi (simetris, } \\
\text { asimertis, central). }\end{array}$ & $1-5$ & & \\
\hline & & & $\begin{array}{l}\text { Kesesuaian ukuran objekyang digambar } \\
\text { dengan ukuran kertas gambar yang dipakai } \\
\text { (gambar tidak terlalu besar dan tidak terlalu } \\
\text { kecil) }\end{array}$ & $1-5$ & & \\
\hline & & & $\begin{array}{l}\text { Pengorganisasian unsur - unsur rupa yang } \\
\text { memancarkan kesatupaduan }\end{array}$ & $1-5$ & & \\
\hline \multirow[t]{4}{*}{6} & Terang Gelap & 20 & $\begin{array}{l}\text { Penyesuaian arsiran dengan kesan volume tau } \\
\text { dimensi. }\end{array}$ & $1-5$ & & \\
\hline & & & $\begin{array}{l}\text { Keberanian dalam menggunakan arsiran pada } \\
\text { gambar. }\end{array}$ & $1-5$ & & \\
\hline & & & Gelap terang terlihat lebih jelas pada gambar. & $1-5$ & & \\
\hline & & & Terlihat perbedaan antara sisi gelap terang. & $1-5$ & & \\
\hline \multirow[t]{2}{*}{7} & Penyelesaian & 5 & Objek gambar terkesan rapi dan bersih & $1-5$ & & \\
\hline & Jumlah & 100 & & & & \\
\hline
\end{tabular}

Sumber tabel Sugito( 2021) dalam buku Evaluasi Hasil Belajar Seni Rupa

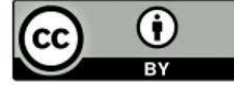




\section{HASIL DAN PEMBAHASAN}

Sesuai teknik pengumpulan data yang menggunakan teknik tes, yaitu tes kemampuan menggambar bentuk dengan menggunakan metedo pembelajaran discovery. Hasil tes pertama, kedua dan ketiga observasi oleh ketiga orang penilai dengan maksud untuk mendapatkan nilai sebagai data yang valid.

Penilai 1. Diperoleh penilaian 40 karya oleh penilai 1 yang menunjukan secara umum hasil karya dalam menggambar bentuk siswa kelas X SMA Negeri 1 Pollung berada pada kategori B (Baik) sebanyak 25 orang, dengan jumlah nilai $=3284$ dan nilai rata - rata $=82,1$

Penilai 2. Berikutnya diperoleh penilaian 40 karya oleh penilai 2 yang menunjukan secara umum dalam menggambar bentuk siswa dengan metode discoveri kelas X SMA Negeri 1 Pollung berada pada kategori B (Baik) sebanyak 24 orang, dengan jumlah nilai 3286 dan nilai rata - rata =82,7.

Penilai 3. Diperoleh penilaian 40 karya oleh penilai 3 yang menunjukan secara umum dalam menggambar bentuk siswa kelas X SMA Negeri 1 Pollung berada pada kategori B (Baik) dengan jumlah nilai $=3251$ dan nilai rata - rata $=81,5$

Tabel 1 Hasil Analisis Uji Normalitas

\begin{tabular}{lllll}
\hline Variable & $\mathrm{N}$ & $L_{\text {Hitung }}$ & $L_{\text {Tabel }}$ & Ket \\
\hline \multirow{3}{*}{ Menggambar bentuk } & $4 \mathrm{O}$ & 0,8744 & 1,40 & Normal \\
\cline { 2 - 5 } & 40 & 0.9956 & 1,40 & Normal \\
\cline { 2 - 5 } & 40 & 0,9973 & 1,40 & Normal \\
\hline
\end{tabular}

Bedasarkan table 1, maka diketahui bahwa data hasil menggambar bentuk berdistribusi normal yang dibuktikan dengan uji normalitas dimana nilai dari ke 3 varibael tersebut adalah $L_{\text {Hitung }} 0,8744<$ $L_{\text {Tabel }} 1,40, L_{\text {Hitung }} 0,9956<L_{\text {Tabel }} 1,40$, dan $L_{\text {Hitung }} 0,9973<L_{\text {Tabel }} 1,40$.

Berdasarkan keterangan pada tael diatas dapat disimpulkan bahwa ketiga data varibel penelitian berdistribusi normal.

Tabel 2 Rangkuman Uji Linieritas antara $X \_(1)$ dengan $Y$

\begin{tabular}{llllll}
\hline Sumber variasi & JK & DK & RJK & $F_{\text {hitung }}$ & $F_{\text {tabel }} \alpha=0,05$ \\
\hline Total & 265286 & 40 & & & \\
\hline Regresi (a) & 264712,9 & 1 & 264712,4 & & \\
Regresi (b/a) & 559,8 & 1 & 559,8 & $1.599,4$ & 4,10 \\
Residu & 13,3 & 38 & 0,35 & & \\
\hline Tuna cocok & -888 & 14 & $-63,4$ & & \\
Galat & 901,33 & 24 & 37,5 & 1,69 & 2,11 \\
\hline
\end{tabular}

Berasarkan tabel diperoleh bahwa $F_{\text {tabel }}$ dengan DK $(14,24)$ pada $\alpha=0,05$ adalah 2,11 sedangkan $F_{\text {hitung }}$ diperoleh 1,69 dan ternyata $F_{\text {tabel }}>F_{\text {hitung }}$ sehingga persamaan regresi tersebut linier. Selanjutnya uji signifikan dengan DK $(1,38)$ pada $\alpha=0,05$ diperoleh $F_{\text {tabel }} 4,10$ sedangkan $F_{\text {hitung }} 1599,4$ dan ternyata $F_{\text {tabel }}<F_{\text {hitung }}$ sehingga persamaan regresi $X_{1}$ dan $Y$ adalah signifikan. Dengan demikian dapat disimpulkan bahwa persamaan regresi $\widehat{Y}=300,06+0,9 X_{1}$ mempunyai hubungan yang linier dan signifikan pada taraf kepercayaan $\alpha=0,05$.

\section{Analisis korelasi}

Bertujuan untuk mengetahui derajat hubungan kontribusi variable bebas dan varibael terikat. Derajat hubungan antara variabel dimaksud seberapa kuat hubungan antara variabel - variabel, berikut ini disajikan rangkuman analisis korelasi.

Besar Hubungan. Besar hubungan antara kemampuan menggambar bentuk $\left(X_{1}\right)$ dengan hasil belajar menggambar bentuk $(\mathrm{Y})$, besar hubungan yang diperoleh adalah $r_{\text {hitung }}=0,98$ berkriteria korelasi sangat kuat. Bila menggunakan table kriteria table product moment maka untuk taraf nyata $\alpha=$ 0,05 dengan $\mathrm{n}=40$ kriterianya dalah 0,312, harga r yang diperoleh melebihi kriteria $\left(r_{\text {hitung }}>r_{\text {tabel }}\right)$

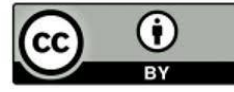


dan tentunya berkorelasi sangat kuat, dengan demikian dapat diartikan bahwa variabel X1 dan Y memiliki hubungan yang kuat.

Besar hubungan antara kemampuan menggambar bentuk $\left(X_{2}\right)$ dengan hasil belajar menggambar bentuk (Y), besar hubungan yang diperoleh adalah $r_{\text {hitung }}=0,49$ berkriteria korelasi sedang. Bila menggunakan table kriteria table product moment maka untuk taraf nyata $\alpha=0,05$ dengan $\mathrm{n}=40$ kriterianya dalah 0,312, harga $r$ yang diperoleh melebihi kriteria $\left(r_{\text {hitung }}>r_{\text {tabel }}\right)$ dan tentunya berkorelasi sangat kuat, dengan demikian dapat diartikan bahwa variabel X2 dan Y memiliki hubungan yang kuat.

Besar Sumbangan. Besar sumbangan (kontribusi) antara kemampuan menggambar bentuk dengan metode pembelajaran discovery (X1) dengan hasil belajar menggambar bentuk (Y). diperoleh 96 $\%$ artinya bahwa kemampuan menggambar bentuk dengan metode pembelajaran discovery (X1) memberi kontribusi atau masukan (sumbangan) menggambar bentuk (Y) rata - rata $96 \%$ sisanya 4\% variabel lain.

Selanjutnya besar sumbangan (kontribusi) antara kemampuan menggambar bentuk dengan metode pembelajaran discovery (X2) dengan hasil belajar menggambar bentuk (Y). diperoleh $24 \%$ artinya bahwa kemampuan menggambar bentuk dengan metode pembelajaran discovery (X2) memberi kontribusi atau masukan (sumbangan) pada menggambar bentuk (Y) rata - rata $24 \%$ sisanya $76 \%$ variabel lain.

\section{Uji Signifikan}

Signifikan hubungan antara kemampuan menggambar bentuk dengan metode pembelajaran discovery (X1) dengan hasil belajar menggambar bentuk (Y) $t_{\text {hitung }}=30,20$ untuk DK $=\mathrm{n}-2=38 \alpha$ $=0,05 t_{\text {tabel }}=1,684$ ternyata $t_{\text {hitung }}>t_{\text {tabel }}(30,20>1,684)$, artinya antara variabel X1 dn Y memiliki hubungan yang sangat signifikan atau yang berarti, antara kemampuan menggambar bentuk dengan metode pembelajaran discovery (X1) dengan hasil belajar menggambar bentuk (Y).

Selanjutnya signifikan hubungan antara kemampuan menggambar bentuk dengan metode pembelajaran discovery $(\mathrm{X} 2)$ dengan hasil belajar menggambar bentuk $(\mathrm{Y}) t_{\text {hitung }}=3,46$ untuk DK= $\mathrm{n}-2=38 \alpha=0,05 t_{\text {tabel }}=1,684$ ternyata $t_{\text {hitung }}>t_{\text {tabel }}(3,46>1,684)$, artinya antara variabel X1 dn $Y$ memiliki hubungan yang sangat signifikan atau yang berarti, antara kemampuan menggambar bentuk dengan metode pembelajaran discovery $(\mathrm{X} 2)$ dengan hasil belajar menggambar bentuk $(\mathrm{Y})$.

\section{SIMPULAN}

Terdapat hubungan yang signifikan antara metode pembelajaran discovery terhapadap hasil belajar menggambar bentuk peserta didik kelas X SMA Negeri 1 Pollung.Berdasarkan uji korelasi dengan taraf signifikan 5\% sebesar 1,684 diperoleh $t_{\text {hasil }}$ dari ketiga percobaan diperoleh Adalah $30,20,3,46$, dan 43,14. Dari hasil yang didapat dapat disimpulkan bahwa probalitas 30,20 >1,684, 3,46>1,648 dan 43,14 >1,684. Dengan demikian $H_{o}$ ditolak dan $H_{a}$ diterima yang dapat disimpulkan bahwa ada hubungan penggunaan metode pembelajaran discovery terhadap hasil belajar mengambar bentuk siswa.

\section{DAFTAR PUSTAKA}

Helmiati. (2012). Model Pembelajaran. Yogyakarta : Aswajaya Pressindo.

Ibrahim, A. \& Budiwiwaramuji, D. (2018). Buku Ajar Strategi Pembelajaran Seni Rupa. Medan : Unimed Press. Ilahi, M. T. (2016). Pembelajaran Discovery Strategy \& Mental Vocational Skill. Jogjakarta : Diva Press.

Kamsinah. (2008). Metode Dalam Proses Pembelajaran : studi tetang ragam dan implementasinya. Lentaran pendidikan, Vol. 11 No. 1.

Laksana, D. A. D. (2013). Menggambar 1 Hand Out. Semarang. Universitas Dian Nuswantoro.

Mesra. 2014. Menggambar Bentuk 1. Medan : _Unimed Press.

Ningsih R. F. (2016) Penggunaan Metode Discovery Learning Bermedia Audio Visual Terhadap Hasil Belajar Menggambar Bentuk. Universitas Negeri Padang

Paramita, N., Azmi, A., \& Azis, A. (2020). Upaya Meningkatkan Hasil Belajar Menggambar Bentuk Buah Teknik Krayon. Journal of Education, Humaniora and Social Sciences (JEHSS), 3(1), 171-177. doi:https://doi.org/10.34007/jehss.v3i1.245

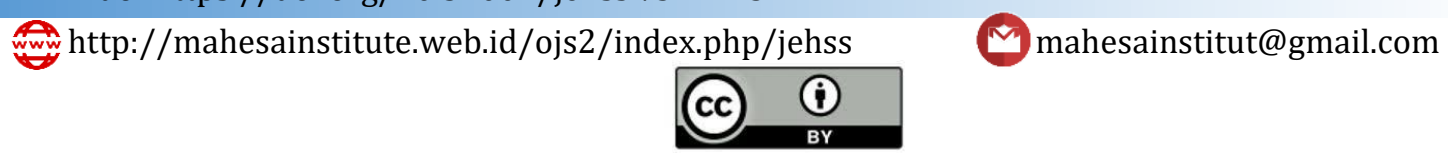


Sani, R A. (2019) . Strategi Belajar Mengajar. Depok : RajaGrafindo Persada.

Septianingrum, F. (2012). Upaya Meningkatkan Kreativitas Siswa Dalam Menggambar Motif Batik Dengan Metode Discovery-Inquiry Di Kelas VII A SMP Negeri 2 Simo Boyolali Tahun Ajaran 2012/2013. Universitas Sebelas Maret

Septianingrum, F. (2012). Upaya Meningkatkan Kreativitas Siswa Dalam Menggambar Motif Batik Dengan Metode Discovery-Inquiry Di Kelas VII A SMP Negeri 2 Simo Boyolali Tahun Ajaran 2012/2013. Universitas Sebelas Maret

Sudjana, N. (2017). Dasar - Dasar Proses Belajar Mengajar. Bandung :Sinar Baru Algensindo.

Sudjana. (2005). Metode statistik. Bandung : PT. Tatsito.

Veermans, K. (2003). Intelligent support for Discovery learning. Twente: Twente University Press.

Yakob. M \& Sari. M. (2019). Peningkatan kemampuan Siswa SMP Membaca Puisi Dengan Metode Pembelajaran Aktif Kreatif dan Menyenangkan. Journal of Education, Humaniora and Social Sciences (JEHSS). 2 (1):93 - 103. 